\title{
Role of Picchavasthi in the Management of Grahani w.s.r Irritable Bowel Syndrome
}

\author{
Case Report
}

\section{Padma Priya $^{1^{*}}$, Praveen Kumar Madikonda ${ }^{2}$, Johar B $^{3}$}

1. PG Scholar, 2. Associate Professor, 3. H.O.D,

P.G Department of Panchakarma, Dr. B.R.K.R.Govt. Ayurvedic Medical College, Hyderabad, Telangana State

\begin{abstract}
'Grahani' is chronic disease of Annavaha srotas related to Agni. Ayurveda considers it as a Tridoshaja $v y a d h i$, which occurs due to the depletion of jataragni by samana Vayu, pachaka pitta and kledaka kapha. It is characterised by indigestion, altered stool consistency and disturbed bowel habits. The symptoms of Grahani resemble those of Irritable Bowel Syndrome. It is a very common digestive disorder which is affecting nearly 10 to $20 \%$ of the population around the world. Young women are affected more often than men. Scientific research has linked it to stress and anxiety but as yet the exact cause of the disease is unknown. Treatment in contemporary system gives symptomatic relief and sometimes result in side effects also. The present study is an observational study using Piccha vasthi which was prepared as per the reference given in Susruta Samhita Chikista Stana with slight modification. Ingredients include Shalmali kanta chooran, Krishna tila pisti, Gritha, Madhu, Dugdha used for piccha vasthi in a quantity of $160 \mathrm{ml}$ given continuously for 14 days. It gave good symptomatic relief to the patient and noticed no recurrence even after a year.
\end{abstract}

Keywords: Grahani, Piccha vasthi, Irritable Bowel Syndrome.

\section{Introduction}

'Grahani' is a chronic disease of Annavaha srotas related to Agni. Ayurveda considers it as a Tridoshaja vyadhi, which occurs due to the depletion of jataragni by samana Vayu, pachaka pitta and kledaka $k a p h a$, it is characterised by indigestion, altered stool consistency and disturbed bowel habits. (1)

The symptoms of Grahani resemble those of Irritable Bowel Syndrome (IBS). It is functional bowel disorder characterized by abdominal pain or discomfort and altered bowel habits in the absence of detectable structural abnormalities. No clear diagnostic markers exist for IBS; thus, the diagnosis of the disorder is based on clinical presentation.

IBS is one of the most common conditions encountered in clinical practice but one of the least well understood. Throughout the world, about $10-20 \%$ of adults and adolescents have symptoms consistent with IBS, and most studies show a female predominance. IBS symptoms tends to come and go over time and often overlap with other functional disorders such as fibromyalgia, headache, backache and genitourinary symptoms. Severity of symptoms varies and can significantly impair quality of life, resulting in high health care costs. (2) Treatment in contemporary system gives symptomatic relief and sometimes result in side effects also. Thus, it gave big scope to alternative system of medicine to find effective therapy to treat IBS.

\footnotetext{
*Corresponding Author:

Padma Priya N,

PG Scholar, Department of Panchakarma,

Dr. BRKR Government Ayurvedic Medical College,

Erragadda, Hyderabad. Telangana State

Email: sunkararao18@gmail.com
}

\section{Aims and Objectives}

1) To verify the efficacy of the simpler version of Piccha Vasthi in the patient of IBS.

2) To administer Piccha Vasthi in a yapana vasthi pattern.

\section{Materials and Methods}

The present study is an observational study. Patient was administered with Piccha Vashti for a period of 14 days in yapana Vasthi pattern based on therapy guidelines on Piccha Vasthi by Acharya Susruta (3) with slight modification.

\section{Pathophysiology of Irritable Bowel Syndrome}

The pathogenesis of IBS is poorly understood, although roles of abnormal gut motor and sensory activity, central neural dysfunction, psychological disturbances, stress, and luminal factors have been proposed. (4)

Patients with diarrhea as a predominant symptom exhibit clusters of rapid jejunal contraction waves, rapid intestinal transit and an increased number of fast and propagated colonic contraction.

Those who are predominantly constipated have decreased orocaecal transit and a reduced number of high-amplitude, propagated colonic contraction waves but there is no consistent evidence of abnormal motility.

IBS is associated with increased sensitivity to intestinal distension induced by inflation of balloons in the ileum, colon and rectum, a consequence of altered CNS processing of visceral sensation. This is more common in diarrhoea predominant IBS. Between 7 and $32 \%$ of patients develop IBS following an episode of gastroenteritis and others may be intolerant of specific dietary components, particularly lactose and wheat. Abnormalities of gut microflora leading to increased 
fermentation and gas production and minimal inflammation have also been postulated. Some patients have subtle, histologically undetectable mucosal inflammation, possibly leading to activation of inflammatory cells and release of cytokines, nitric oxide and histamine. These may trigger abnormal secretomotor function and sensitise enteric sensory nerve endings. (5)

\section{Pathogenesis of Grahani Roga}

The main cause of Grahani is agni dushti which brings indigestion, the resulted semi digested food moves upward and downward in the gastrointestinal tract. The condition of downward movement of indigested food is called Grahani roga. The predominant symptom is passing of stool in large quantity either in solid or liquid form associated with thirst, excessive salivation, anorexia, vomiting, fever, oedema in legs and hands and pain in bones and phalanges etc. (6)

\section{Line of Management of Grahani Roga}

SNEHA, SWEDA, PANCHAKARMA, LANGANA, DEEPANA, LAVANA \& KSHARA PRAYOGA, MADVARISHTA SURA \& ASAVA PRAYOGA, TAKRA PRAYOGA AND DIPANA SARPIS. (7)

\section{PICCHA VASTHI:}

It is one of the popular therapeutic modalities practiced in Ayurveda. Two varieties of Piccha vasthi were mentioned by Charka in chikista stana while dealing with the management of Arsas (8) and Atisara (9) with some slight variation. But Acharya Susruta, while mentioning management for the complications of virechana karma, has brought a very simple version of piccha vasthi with few ingredients. In present study, patient was administered with piccha vasthi with slight modification from that propounded by Acharya Susruta as detailed below.

Table 1: Drug Schedule and Dosage:

\begin{tabular}{|l|l|}
\hline Madhu & $30 \mathrm{gms}$ \\
\hline Go Gritha & $30 \mathrm{gms}$ \\
\hline Kalka - Krishna tila Pishti & $20 \mathrm{gms}$ \\
\hline $\begin{array}{l}\text { Kwatha-Mocha rasa(10gms) siddha } \\
\text { Kheera paka (320 ml of milk) }\end{array}$ & $80 \mathrm{ml}$ \\
\hline Total & $160 \mathrm{ml}$ \\
\hline
\end{tabular}

\section{Properties of the drugs used in Piccha vasthi}

Shalmali Niryasa: (Gum of Silk Cotton Tree)

Rasa: Kashaya; Virya: Sheeta; Vipaka: Madhura

Shalmali Niryasa is Hima (cool in Potency), Grahi (absorbent), Snigdha (demulcent), Vrishya (aphrodisiac) and cures dysentery, diarrhoea, retained undigested food, burning sensation and diseases of Kapha, Pitta and Rakta. (10)

\section{Krishna Tila Pishti: (Black sesamum seeds)}

Rasa: Madhura, tikta, kashaya,; Virya: Ushna; Vipaka: katu

Tila cures Kapha, Pitta diseases. It is Balya (acts as general tonic), Keshya (hair tonic), Twachya (good for skin), Stanya (increases breast milk), Vrano Hitham (heals ulcers), Dantya (strengthens teeth), Alpa Mutra Krudh (reduces the quantity of urine), Grahi (absorbent), Vatagno (pacifies vata), Agnimatipradha (promotes digestive power and intellect).(11)

\section{Gritha (Ghee):}

Rasa: Madhura; Virya: Sheeta; VIpaka: Madhura Its properties are Agni deepana (promotes digestive fire), Alpabhishyandi (it causes very minimal or no obstruction to the channels), Cakshushya (beneficial for vision), Medya (increases memory power), Pittanila haram (pacifies vata and pitta), Kanthi vardhaka (increases brightness), Ojovardhakam (increases immunity), Lavanya Vardhakam (Increases lusture), Ayurvardakam (increases life span) and Swarsmrithikaram (promotes voice and memory power). (12)

\section{4) Dugdha (Milk):}

Rasa: Madhura; Virya: Sheeta; Vipaka: Madhura

Its properties are Vata Pitta haram (pacifies vata and Pitta), Saram (mobile in nature), Sadha Sukrakaram (Promotes semen instantaneously), Sheetalam (cool in nature), Satmyam sarva Shareeranam (suitable to all persons). Jeevaniyam (life promoter). Brhimanam (nutritious), Vajikaram (aphrodisiac), Vaya Stapanam (life stabilizer), Sandhikaram (heals up fractures), Rasayam (Tissue vitalizer), Dosha Dhatu Mala Srotasaam kinchith kledakaram (It enhances mild moisture to Dosha, Dhatu, Mala and Srotas). (13)

\section{5) Madhu (Honey):}

Rasa: Madhura; Anurasa: Kashaya; Virya: Sheeta; Vipaka: Madhura

It has properties like Grahi(absorbent) Vilekanam (depletor of body fats) Deepanam (appetizer) Vranashodanaropanam (clears and heals ulcers) etc. It is helpful in treating skin diseases, cough, hemorrhoids, urinary tract disorders, worm infestations, diarrhoea and constipation. Its Yogavahi property helps in speeding up the vasthi action (14).

\section{Case Report}

A 46-year-old male patient came to Panchakarma OPD of Dr. B.R.K.R.Govt. Ayurvedic College and Hospital (OP regd. No.21867) with complaints of passing watery stools containing semi digested food and mucous, 10-12 times a day for the last four years. He also complained of indigestion, abdominal bloating, severe pain abdomen before and while passing stools which was relieved after passing stools. Earlier, he was treated in contemporary system of medicine with Antidiarrheal, anti- amoebic, anti-cholinergic and antidepressants for many months with minimal improvement. On his first consultation, he was advised ayurvedic oral medications like Bilvadi Gutika, Dadimashataka Chooran and Mustarishta for a period of one month which resulted in symptomatic relief only. Therefore, Piccha vasthi was planned which resulted in significant improvement in a very short span of time that sustained for more than a year as detailed below. 
Treatment Protocol

Procedure

Purva Karma: Performed Sthanika abyangana with tila taila and Nadi sweda before administration of vasthi.

Pradana Karma: Patient was made to lie in left lateral position for administration of vasthi. Light diet advised 2 hours before administration of vasthi.

Paschat Karma: Lifting the legs, patting to the buttocks and anti-clock wise massage to the abdomen done. Dietetic and behavioral regimen explained. (15)

Duration of Treatment: Continuously for 14 days in yapana vasthi Schedule.

Assessment Criteria: Improvement of the Patient was assessed on the basis of relief in the subjective parameters. All the subjective parameters were scored and assessed before and after treatment.

Table 2: Gradation of Subjective Parameters

\begin{tabular}{|c|c|c|}
\hline Sl.no & Signs and Symptoms & Gradation \\
\hline \multirow[t]{6}{*}{1} & Bowel Frequency & \\
\hline & 1or 2 times in a day & 0 \\
\hline & 3 to 4 times in a day & 1 \\
\hline & 5 to 7 times in a day & 2 \\
\hline & 8 to 10 times in a day & 3 \\
\hline & More than 10 times in a day & 4 \\
\hline \multirow[t]{6}{*}{2} & Mucus in stool & \\
\hline & No mucus in stool & 0 \\
\hline & $\begin{array}{l}\text { Mucus present occasionally in } \\
\text { stool (not daily) }\end{array}$ & 1 \\
\hline & $\begin{array}{l}\text { Mucus present in initial stools } \\
\text { only }\end{array}$ & 2 \\
\hline & $\begin{array}{l}\text { Mucus present in more than } 6 \\
\text { stools per day }\end{array}$ & 3 \\
\hline & Mucus present in every stool & 4 \\
\hline \multirow[t]{6}{*}{3} & Abdominal Bloating & \\
\hline & No Bloating & 0 \\
\hline & Minimal Bloating & 1 \\
\hline & $\begin{array}{l}\text { Moderate Bloating relieved } \\
\text { after passing stool }\end{array}$ & 2 \\
\hline & $\begin{array}{l}\text { Mild Bloating present even } \\
\text { after passing stool }\end{array}$ & 3 \\
\hline & $\begin{array}{l}\text { Bloating present before and } \\
\text { after passing stools }\end{array}$ & 4 \\
\hline
\end{tabular}

Table 3: Assessment of symptoms of IBS Before and After Therapy:

\begin{tabular}{|l|l|l|l|}
\hline $\begin{array}{l}\text { Sl. } \\
\text { N } \\
\text { o }\end{array}$ & $\begin{array}{l}\text { Signs and } \\
\text { Symptoms } \\
\text { (Subjective } \\
\text { Parameters) }\end{array}$ & $\begin{array}{l}\text { Before } \\
\text { treatment }\end{array}$ & $\begin{array}{l}\text { After } \\
\text { treatment }\end{array}$ \\
\hline 1 & Bowel Frequency & 4 & 0 \\
\hline 2 & Mucus in stool & 2 & 0 \\
\hline 3 & $\begin{array}{l}\text { Abdominal } \\
\text { Bloating }\end{array}$ & 3 & 0 \\
\hline
\end{tabular}

Figure 1 : Showing the Assessment of symptoms of IBS Before and After Therapy

ASSESSMENT OF SYMPTOMS OF IRRITABLE BOWEL SYNDROME BEFORE AND AFTER TREATMENT

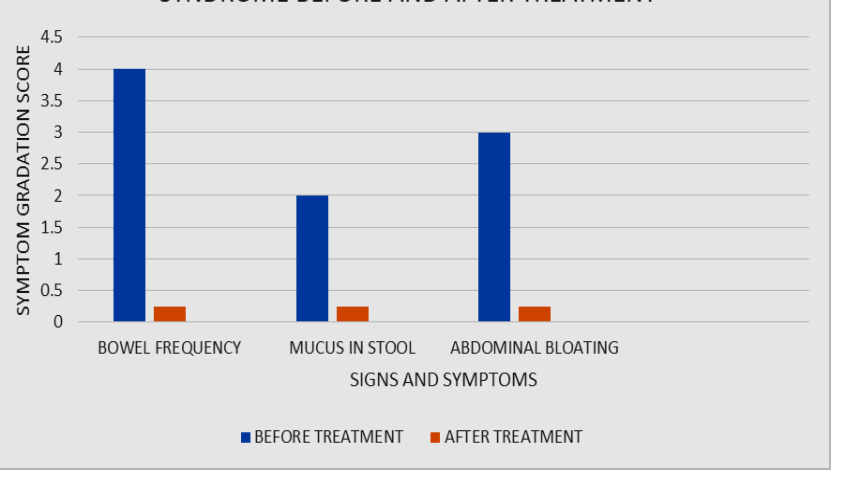

Discussion

Grahani Roga is a chronic disease of Annavaha srotas which occur in organ Grahani due to vitiation of agni. Acharya Vagbhata included it in Ashtamaha Gadhas which are hard to diagnose and difficult to treat. (16) Grahani roga is the prime disease of gastrointestinal tract which is most often found in clinical practice. It disturbs daily routine of individuals.

Vasthi karma is the most important among Panchakarmas due to its multiple benefits. It is the best procedure for vata disorders. It is also effective in correcting the morbid pitta, kapha and rakta (17). Acharya Charaka considered Vasthi karma as artha chikista for all diseases (18) while some other authors consider it as the complete remedy for all the ailments. Various types of vasthi karma are mentioned in classics based on their action and one of them is Piccha vasthi. It is named because of its picchila property which means sticky or lubricant in nature. Because of this property, it forms a protective layer over the intestinal mucosa to avoid friction and reduction in intestinal irritation. In the present study Susruta version of piccha vasthi was performed on a patient with IBS. The ingredients used in piccha vasti were Shalmali niryasa, Krishna tila pista, Gritha, Madhu and Dugdha. Many of them have similar properties like Madura rasa, Sheeta veerya and Madura paka. By virtue of these properties, it acts as pitta shamaka, shota hara, vrana ropana, rakta stambaka etc. These are helpful in controlling Grahani roga. The whole combination of above mentioned ingredients was administered in the form of Yapana vasthi in a quantity of $160 \mathrm{ml}$ each day for a period of 14 days. The result was very significant in terms of complete remission of symptoms which was assessed in terms of improvement observed in gradation scores of bowel frequency, mucous in stool and abdominal bloating.

\section{Conclusion}

Piccha vasthi was prepared from easily available herbs and after administration, it gave good symptomatic relief to the patient and there was no recurrence even after one year. Hence, in view of the above and the complications attached to contemporary system, the piccha vasthi is definitely a better option to treat Grahani w.s.r to IBS. 


\section{References}

1. Ram Karan Sharma, Bhagwan Dash. Charaka Samhita of Acharya Agnivesha. Reprint 2017, Varanasi; Chowkamba Sanskrit Series office;2017, Vol.IV, Chikista Sthana, Chapter XV, 28p

2. Fauci, Braunwald, Kasper, Hauser, Longo, Jameson, Loscalzo. Harrison's Principles of Internal Medicine by Harrison.T.R. $17^{\text {th }}$ edition, USA; Mc Graw-Hill Companies; 2008. Vol.II, Part 13,1899p

3. Singhal.G.D. Susruta Samhita of Acharya Susruta. Reprint 2015, Delhi; Chowkamba Sanskrit Pratishthan; 2015. Vol.II, Chikista Sthana, Chapter XXXIV,477p

4. Fauci, Braunwald, Kasper, Hauser, Longo, Jameson, Loscalzo. Harrison's Principles of Internal Medicine by Harrison.T.R. $17^{\text {th }}$ edition, USA; Mc Graw-Hill Companies;2008, Vol.II, Part XIII,1900p

5. Nicholas A. Boon, Nicki R. Colledge, Brain R. Walker. Davidson's Principles \& Practice of Medicine by Sir Stanley Davidson.20 ${ }^{\text {th }}$ edition, Philadelphia; An Imprint of Elsevier limited;2006, chapter XXII,921p

6. Ram Karan Sharma, Bhagwan Dash. Charaka Samhita of Acharya Agnivesha. Reprint 2017, Varanasi; Chowkamba Sanskrit Series office;2017, Vol.IV, Chikista Sthana, Chapter XV, 28p

7. Ram Karan Sharma, Bhagwan Dash. Charaka Samhita of Acharya Agnivesha. Reprint 2017, Varanasi; Chowkamba Sanskrit Series office;2017, Vol.IV, Chikista Sthana, Chapter XV, 66p

8. Ram Karan Sharma, Bhagwan Dash. Charaka Samhita of Acharya Agnivesha. Reprint 2017, Varanasi; Chowkamba Sanskrit Series office;2017, Vol.III, Chikista Sthana, Chapter XIV, 627p
9. Ram Karan Sharma, Bhagwan Dash. Charaka Samhita of Acharya Agnivesha. Reprint 2017, Varanasi; Chowkamba Sanskrit Series office;2017, Vol.IV, Chikista Sthana, Chapter XIX, 240p

10. Bulusu Sitaram, Chunekar.K.C. Bhavaprakaa of Bhavamisra.Ist edition, Varanasi; Chaukambha Orientalia; 2006, Vol.I Chapter (6) VI,353p

11. Bulusu Sitaram, Chunekar.K.C. Bhavaprakaa of Bhavamisra.Ist edition, Varanasi; Chaukambha Orientalia; 2006, Vol.I Chapter (6) IX,437p

12. Bulusu Sitaram, Chunekar.K.C. Bhavaprakaa of Bhavamisra.Ist edition, Varanasi; Chaukambha Orientalia; 2006, Vol.I Chapter (6) XVIII,537p

13. Bulusu Sitaram, Chunekar.K.C. Bhavaprakasha of Bhavamisra.Ist edition, Varanasi; Chaukambha Orientalia; 2006, Vol.I Chapter (6) XIV,522p

14. Bulusu Sitaram, Chunekar.K.C. Bhavaprakasha of Bhavamisra.Ist edition, Varanasi; Chaukambha Orientalia; 2006, Vol.I Chapter (6) XXII,550p

15. Ram Karan Sharma, Bhagwan Dash. Charaka Samhita of Acharya Agnivesha. Reprint 2017, Varanasi; Chowkamba Sanskrit Series office;2017, Vol.VI, Siddhi Sthana, Chapter XII, 430p

16. Srikantha Murthy.K.R. Ashtanga Hridayam of Acharya Vagbhata. Reprint 2018, Varanasi; Chowkamba Krishnadas Academy; 2018, Vol.II, Nidana Sthana, Chapter VIII, 83p

17. Singhal.G.D. Susruta Samhita of Acharya Susruta. Reprint 2015, Delhi; Chowkamba Sanskrit Pratishthan; 2015. Vol.II, Chapter XXXV,482p

18. Ram Karan Sharma, Bhagwan Dash. Charaka Samhita of Acharya Agnivesha. Reprint 2017, Varanasi; Chowkamba Sanskrit Series office;2017, Vol.VI, Siddhi Sthana, Chapter I,163p 